\title{
MEAT PRODUCTION POTENTIAL OF DIFFERENT CROSS-BRED DUCKLINGS
}

\author{
E. Ansary ${ }^{1}$, M. Mahiuddin*, M. A. R. Howlider ${ }^{1}$ and M. A. Hai ${ }^{2}$
}

\begin{abstract}
A study was conducted to determine the meat production potential of Pekin $(\mathrm{P}) \times$ Pekin (P), $\mathrm{P} \times$ Desi (D) and $\mathrm{P} \times$ Jinding (J) ducklings up to 8 weeks of age. 54 day old ducklings were randomly allocated to 3 genotypic treatments having 3 replications in each genotype. One duckling from each replication was dissected to determine the meat yield. The initial and final live weight was found highest $(\mathrm{P}<0.01)$ in $\mathrm{P} \mathrm{X} \mathrm{P}$, followed by those of P X D and P X J ducklings respectively. Feed conversion was poor in P X J, better in P $\mathrm{X} P$ and best in $\mathrm{P} X \mathrm{D}(\mathrm{P}<0.01)$. However, feed conversion for all genotypes decreased with the advance of age. At all ages except $1^{\text {st }}$ week, better feed utilization was observed in P X D crossbred than that in P X P and P X J. Higher breast meat was observed in P X $\mathrm{P}(\mathrm{P}<0.05)$ than in $\mathrm{P} X \mathrm{D}$ and $\mathrm{P} X \mathrm{X}$. Thigh meat was found higher $(\mathrm{P}<0.05)$ in $\mathrm{P} \mathrm{X} \mathrm{P}$ and $\mathrm{P} X \mathrm{D}$ than that in $\mathrm{P} X \mathrm{X}$. Considering the growth performance (growth rate and feed utilization) and meat yield characteristics, it may be concluded that crossing of Pekin with local ducks might produce a suitable genotype to improve meat production potential of duck to reared under Bangladesh condition.
\end{abstract}

Key words : Duckling, Genotype, Growth, Meat production

\section{Introduction}

The supply and demand gap of animal protein can be met by increasing the production of poultry meat. Among poultry, raising of ducks is more profitable in Bangladesh. Ducks can be easily brooded, considerably cheaper to raise, do not require any elaborate and expensive housing and equipment, need less care and they are more resistant to diseases and have no cannibalism and agnostic behavior (Batty, 1979; Ahmed, 1986 and Banerjee, 1992). Ducks are natural foragers and thus help to control weed and pests that attack field crops, particularly rice which ultimately helps the farmer (Manda et al., 1993 and Edar et al., 1996). Ducks ranked $2^{\text {nd }}$ place as the supplier of eggs and meat and about $98 \%$ of ducks in Bangladesh are traditionally reared under the existing scavenging system (Salahuddin et al., 1991); 90 to 95\% of which are of Desi (native) type (Ahmed, 1986). In Bangaldesh, the available duck genotypes are Khaki Campbell, Indian Runner, Jinding, Pekin, Muscovy and Desi (Ahmed, 1986). Among these, Pekin is an excellent meat producing duck. But they have poor scavenging ability and high mortality under extensive condition (Ahmed, 1986).

\footnotetext{
* Corresponding author

${ }^{1}$ Department of Poultry Science, Bangladesh Agricultural University, Mymensingh-2202, Bangladesh

${ }^{2}$ Department of Livestock Services, Farmgate, Dhaka, Bangladesh
}

(Received : September 16, 2008) 
Bang. J. Anim. Sci. 2008, 37(2)

On the contrary, Desi birds are well adapted to poor management and rural conditions of Bangladesh (Khan, 1983; Hussain et al., 1988 and DLS, 1990). The crossing of Desi type with desired exotic breeds is highly advantageous than the total replacement of the Desi ducks by standard breeds to rear them in rural farming. Therefore, it may be better to introduce desirable genes from Pekin to progeny by crossing Desi and egg type females with Pekin male. Information in relation to meat yield performance of different pure and crossbred ducklings under Bangladesh condition is very scanty. This study was therefore, designed to compare meat production potential of different genotypes (Pekin x Pekin, Pekin $\mathrm{x}$ Desi and Pekin $\mathrm{x}$ Jinding) under local condition and to compare the performance of those different genotypes in terms of growth, feed consumption, feed conversion and meat yield.

\section{Materials and Methods}

The research was conducted at Bangladesh Agricultural University Poultry Farm, Mymensingh. Pekin (P) males were crossed to P, Desi (D) and Jinding (J) females to produce $6 \mathrm{P} \times \mathrm{P}, 17 \mathrm{P} \times \mathrm{D}$ and $6 \mathrm{P} \times \mathrm{J}$ crossbred ducklings. The 54 day old ducklings were randomly selected and distributed equally in 3 genotypic treatments having 3 replications in each genotype. Throughout the experimental period, the ducklings in all genotypes were provided with same dry mash ration containing ME (kcal/kg) 2900, CP (\%) 16.00, Ca (\%) 0.59 , available phosphorus (\%) 0.32 , lysine (\%) 0.75 and methionine (\%) 0.34 . Feed and water were supplied ad libitum to the duckling throughout the experimental period. Each bird was provided with $1100 \mathrm{~cm}^{2}$ floor space.

Initial and weekly live weights up to 56 days of age were recorded. Records on feed consumption were kept on weekly basis up to 56 days of age. The feed conversion ratio was calculated by dividing the total feed consumption by average body weight gain. The survivability of the birds for all treatments and replications were $100 \%$. The birds were dissected following the procedure of Jones (1984). At the end of the experiment, 1 duckling weighing average of pen weight from each replicate were selected, slaughtered and dissected. Dressed carcass weight, blood weight, feather weight, head weight, heart weight, liver weight, gizzard weight, breast meat weight, thigh meat weight, drumstick meat weight, wing meat weight and abdominal fat weight were recorded. Before statistical analysis, data on all meat yield parameters were converted into percentages of respective live weight.

Data were analyzed for a Completely Randomized Design (CRD). Analysis of variance was performed to compare results among the genotypes. Mean differences was done by LSD.

\section{Results}

\section{Growth performance}

Initial live weight and live weight at $2^{\text {nd }}$ week of age were highest in P X P, intermediate in $\mathrm{P}$ $\mathrm{X} \mathrm{J}$ and lowest in $\mathrm{P} X \mathrm{D}(\mathrm{P}<0.01)$. At $1^{\text {st }}$ week, there was no difference in live weight among 
the genotypes $(\mathrm{P}>0.05)$. From $3^{\text {rd }}$ to $8^{\text {th }}$ weeks of age, live weight was observed higher $(\mathrm{P}<0.01)$ in $\mathrm{P} X \mathrm{P}$ than that in $\mathrm{P} \mathrm{X} \mathrm{J}$ and $\mathrm{P} X \mathrm{D}$, where as no difference was found between $\mathrm{P}$ $\mathrm{X} \mathrm{J}$ and $\mathrm{P} X \mathrm{D}$ (Table 1).

Table 1. The growth performance of Pekin (P) X P, P X Desi (D) and P X Jinding (J) ducklings at different ages

\begin{tabular}{|c|c|c|c|c|c|c|}
\hline Parameters & Age (week) & $\mathbf{P} \times \mathbf{P}$ & P X D & P X J & $\begin{array}{c}\text { LSD } \\
\text { (SED) }\end{array}$ & Level of Sig. \\
\hline \multirow{9}{*}{$\begin{array}{l}\text { Live weight } \\
\text { (g/duckling) }\end{array}$} & Initial & $47.33^{\mathrm{a}}$ & $40.06^{c}$ & $44.50^{b}$ & 1.417 & $* *$ \\
\hline & 1 & 158.33 & 112.17 & 132.50 & $(14.425)$ & NS \\
\hline & 2 & $339.17^{\mathrm{a}}$ & $219.00^{c}$ & $276.50^{\mathrm{b}}$ & 42.250 & $* *$ \\
\hline & 3 & $739.17^{\mathrm{a}}$ & $466.67^{b}$ & $523.33^{\mathrm{b}}$ & 76.080 & $* *$ \\
\hline & 4 & $1018.33^{\mathrm{a}}$ & $700.43^{b}$ & $741.67^{\mathrm{b}}$ & 91.970 & $* *$ \\
\hline & 5 & $1366.67^{\mathrm{a}}$ & $902.78^{b}$ & $971.67^{\mathrm{b}}$ & 88.710 & $* *$ \\
\hline & 6 & $1583.33^{\mathrm{a}}$ & $1111.13^{\mathrm{b}}$ & $1220.67^{b}$ & 141.200 & $* *$ \\
\hline & 7 & $1888.33^{\mathrm{a}}$ & $1255.33^{\mathrm{b}}$ & $1410.00^{\mathrm{b}}$ & 308.100 & $* *$ \\
\hline & 8 & $2237.50^{\mathrm{a}}$ & $1647.80^{\mathrm{b}}$ & $1651.67^{b}$ & 287.000 & $* *$ \\
\hline \multirow{8}{*}{$\begin{array}{l}\text { Live weight gain } \\
\text { (g/duckling) }\end{array}$} & 1 & 111.00 & 72.00 & 88.00 & $(14.240)$ & NS \\
\hline & 2 & $291.70^{\mathrm{a}}$ & $183.50^{\mathrm{c}}$ & $232.20^{\mathrm{b}}$ & 41.220 & $* *$ \\
\hline & 3 & $691.70^{\mathrm{a}}$ & $426.50^{\mathrm{b}}$ & $478.80^{\mathrm{b}}$ & 75.470 & $* *$ \\
\hline & 4 & $971.00^{\mathrm{a}}$ & $660.30^{\mathrm{b}}$ & $697.20^{\mathrm{b}}$ & 92.110 & $* *$ \\
\hline & 5 & $1319.00^{\mathrm{a}}$ & $862.60^{\mathrm{b}}$ & $927.20^{\mathrm{b}}$ & 88.820 & $* *$ \\
\hline & 6 & $1536.00^{\mathrm{a}}$ & $1071.00^{\mathrm{b}}$ & $1176.33^{b}$ & 141.100 & $* *$ \\
\hline & 7 & $1841.00^{\mathrm{a}}$ & $1215.05^{\mathrm{b}}$ & $1403.83^{b}$ & 247.800 & $* *$ \\
\hline & 8 & $2190.17^{\mathrm{a}}$ & $1608.56^{\mathrm{b}}$ & $1615.50^{\mathrm{b}}$ & 277.800 & $* *$ \\
\hline \multirow{8}{*}{$\begin{array}{l}\text { Feed intake } \\
\text { (g/duckling) }\end{array}$} & 1 & $250.00^{\mathrm{a}}$ & $177.78^{b}$ & $250.00^{\mathrm{a}}$ & 22.200 & $* *$ \\
\hline & 2 & $928.33^{\mathrm{a}}$ & $545.56^{\mathrm{c}}$ & $806.67^{\mathrm{b}}$ & 79.160 & $* *$ \\
\hline & 3 & $1889.33^{\mathrm{a}}$ & $976.78^{c}$ & $1640.00^{\mathrm{b}}$ & 138.500 & $* *$ \\
\hline & 4 & $2762.67^{\mathrm{a}}$ & $1648.17^{\mathrm{c}}$ & $2296.67^{b}$ & 325.600 & $* *$ \\
\hline & 5 & $4212.67^{\mathrm{a}}$ & $2270.40^{c}$ & $3763.33^{b}$ & 374.300 & $* *$ \\
\hline & 6 & $5812.67^{\mathrm{a}}$ & $3223.17^{\mathrm{c}}$ & $5146.67^{b}$ & 381.500 & $* *$ \\
\hline & 7 & $7261.00^{\mathrm{a}}$ & $4132.06^{\mathrm{c}}$ & $6066.67^{\mathrm{b}}$ & 547.300 & $* *$ \\
\hline & 8 & $8522.67^{\mathrm{a}}$ & $4645.39^{c}$ & $6466.67^{b}$ & 754.200 & $* *$ \\
\hline \multirow{8}{*}{$\begin{array}{l}\text { Feed conversion } \\
\text { (feed intake/ live } \\
\text { weight gain) }\end{array}$} & 1 & 2.35 & 2.47 & 2.88 & $(0.366)$ & NS \\
\hline & 2 & 3.19 & 2.98 & 3.53 & $(0.320)$ & NS \\
\hline & 3 & $2.74^{\mathrm{b}}$ & $2.29^{b}$ & $3.45^{\mathrm{a}}$ & 0.513 & $* *$ \\
\hline & 4 & 2.85 & 2.50 & 3.33 & $(0.261)$ & NS \\
\hline & 5 & $3.20^{\mathrm{b}}$ & $2.63^{b}$ & $4.08^{\mathrm{a}}$ & 0.603 & $* *$ \\
\hline & 6 & $3.79^{\mathrm{b}}$ & $3.01^{\mathrm{c}}$ & $4.40^{\mathrm{a}}$ & 0.599 & $* *$ \\
\hline & 7 & $3.95^{\mathrm{ab}}$ & $3.40^{\mathrm{b}}$ & $4.35^{\mathrm{a}}$ & 0.593 & $*$ \\
\hline & 8 & $3.91^{\mathrm{a}}$ & $2.89^{\mathrm{b}}$ & $4.01^{\mathrm{a}}$ & 0.424 & $* *$ \\
\hline
\end{tabular}

${ }^{\text {abc }}$ Means values in each row with uncommon superscripts differ significantly NS, $\mathrm{P}>0.05 ; *, \mathrm{P}<0.05 ; * *, \mathrm{P}<0.01$; all SEDs are against 6 error d.f. 
Bang. J. Anim. Sci. 2008, 37(2)

At $1^{\text {st }}$ week of age, no differences $(\mathrm{P}>0.05)$ in live weight gain was observed among the genotypes. The live weight gain was observed highest $(\mathrm{P}<0.01)$ in $\mathrm{P} X \mathrm{P}$, intermediate in $\mathrm{P} X$ $\mathrm{J}$ and lowest in P X D at $2^{\text {nd }}$ week of age. From $3^{\text {rd }}$ to $8^{\text {th }}$ week of age, live weight gain was higher $(\mathrm{P}<0.01)$ in $\mathrm{P} X \mathrm{P}$ than that in $\mathrm{P} \mathrm{X} \mathrm{D}$ and $\mathrm{P} \mathrm{X} \mathrm{J}$, where as no difference was found between P X D and P X J (Table 2).

Table 2. The meat yield characteristics of Pekin (P) X P, P X Desi (D) and P X Jinding (J) ducklings at 8 weeks of ages

\begin{tabular}{|l|c|c|c|c|c|}
\hline \multicolumn{1}{|c|}{ Parameters } & P X P & P X D & P X J & LSD (SED) & Level of Sig. \\
\hline Live weight (g/duckling) & $2221.67^{\mathrm{a}}$ & $1916.67^{\mathrm{ab}}$ & $1703.33^{\mathrm{b}}$ & 346.100 & $*$ \\
Dressing yield (\%) & 53.38 & 52.46 & 49.31 & $(2.095)$ & NS \\
Breast meat (\%) & $12.19^{\mathrm{a}}$ & $11.08^{\mathrm{b}}$ & $10.76^{\mathrm{b}}$ & 0.967 & $*$ \\
Thigh meat (\%) & $6.62^{\mathrm{a}}$ & $6.40^{\mathrm{a}}$ & $5.67^{\mathrm{b}}$ & 0.704 & $*$ \\
Drumstick meat (\%) & $4.54^{\mathrm{b}}$ & $5.40^{\mathrm{a}}$ & $4.70^{\mathrm{b}}$ & 0.625 & $*$ \\
Wing meat (\%) & 7.26 & 8.62 & 6.85 & $(0.738)$ & NS \\
Heart (\%) & $0.69^{\mathrm{b}}$ & $0.80^{\mathrm{a}}$ & $0.84^{\mathrm{a}}$ & 0.063 & $* *$ \\
Liver (\%) & 2.77 & 2.95 & 3.03 & $(0.106)$ & NS \\
Gizzard (\%) & 3.16 & 3.73 & 3.52 & $(0.091)$ & NS \\
Feather (\%) & 8.15 & 7.91 & 8.90 & $(0.397)$ & NS \\
Blood (\%) & 5.80 & 6.09 & 6.66 & $(0.544)$ & NS \\
Abdominal fat (\%) & 0.20 & 0.57 & 0.00 & $(0.493)$ & NS \\
\hline
\end{tabular}

${ }^{\mathrm{ab}}$ Means values in each row with uncommon superscripts differ significantly NS, $\mathrm{P}>0.05 ; *, \mathrm{P}<0.05 ; * *, \mathrm{P}<0.01$; all SEDs are against 6 error d.f.

At $1^{\text {st }}$ week of age, feed intake was found higher $(\mathrm{P}<0.01)$ in $\mathrm{P} X \mathrm{P}$ and $\mathrm{P} X \mathrm{~J}$ than that in $\mathrm{P}$ $X \mathrm{D}$ where as no difference was observed between P X P and P X J (Table 1). From $2^{\text {nd }}$ to $8^{\text {th }}$ weeks of age, feed intake was found highest $(\mathrm{P}<0.01)$ in $\mathrm{P} X \mathrm{P}$, intermediate in $\mathrm{P} X \mathrm{~J}$ and lowest in P X D (Table 2).

There was no difference $(\mathrm{P}>0.05)$ in feed conversion among the genotypes at $1^{\text {st }}, 2^{\text {nd }}$ and $4^{\text {th }}$ weeks of age (Table 2). At $3^{\text {rd }}$ and $5^{\text {th }}$ weeks of age, feed conversion was higher $(\mathrm{P}<0.01)$ in P X P and P X D than that in P X J, while no difference was found between P X P and P X D. At $6^{\text {th }}$ and $7^{\text {th }}$ week of age, it was highest $(\mathrm{P}<0.05)$ in $\mathrm{P} X \mathrm{D}$, intermediate in $\mathrm{P} \times \mathrm{P}$ and lowest in P X J. Likewise, feed conversion was higher $(\mathrm{P}<0.01)$ in $\mathrm{P} X \mathrm{D}$ than that in $\mathrm{P} X \mathrm{P}$ and P X J, but no difference was found between P X P and P X J.

\section{Meat yield performance}

Breast meat yield was found higher $(\mathrm{P}<0.05)$ in $\mathrm{P} \mathrm{X} \mathrm{P}$ than that in $\mathrm{P} \mathrm{X} \mathrm{D}$ and $\mathrm{P} X \mathrm{X}$ but no difference was observed between P X D and P X J (Table 2). On the other hand, thigh meat was found similar and higher $(\mathrm{P}<0.05)$ in $\mathrm{P} \mathrm{X} \mathrm{P}$ and $\mathrm{P} \mathrm{X} \mathrm{D} \mathrm{than} \mathrm{that} \mathrm{in} \mathrm{P} \mathrm{X} \mathrm{J}$, where as no 
difference was observed between P X P and P X D. Drumstick meat was found higher $(\mathrm{P}<0.05)$ in $\mathrm{P} X \mathrm{D}$ than that in $\mathrm{P} X \mathrm{P}$ and $\mathrm{P} X \mathrm{~J}$ where as no difference was observed between P X P and P X J. Heart weight was found larger $(\mathrm{P}<0.01)$ in P X D and P X J than that in P X $\mathrm{P}$, while no difference was found between $\mathrm{P} X \mathrm{P}$ and $\mathrm{P} X \mathrm{X}$. On the contrary, there were no differences $(\mathrm{P}>0.05)$ in dressed meat, wing meat, liver, gizzard, feather, blood and abdominal fat among the genotypes.

\section{Discussion}

It is evident from data in Table 2 that Pekin (P) X Desi (D) had lowest initial weight, where as P X P had highest and P X Jinding (J) had intermediate initial weight. Such differences perhaps arose because in difference of egg weight. Crossing of Pekin sire with Desi dam line was more beneficial in improving growth rate than crossing Pekin sire with Jinding dams. Yeong (1986), Nageswara et al., (1998) and Ferdaus (1999) revealed positive heterotic effect of cross breeding in P X D in growth performance that coincides with the results of this study. They compared live weight among the genotypes of P X P, D X D, J X J, P X D and P X J and reported that the live weight at 56 days of age of those genotypes was 2468, $1136,1227,1651$ and $1377 \mathrm{~g}$ respectively while the results of present study shows that the body weight were 2238 (P X P), 1648 (P X D) and 1652g (P X J).

The data on feed intake (Table 2) signify that feed intake in the crossbred ducklings were highly correlated to their body weight. The P X P ducklings in general ate more feed, possibly because of their higher growth potential, which agreed with the previous reports (Yeong, 1986; Modak, 1996 and Ferdaus, 1999). The feed intake of P X P genotypes ranged from 6765 to $9280 \mathrm{~g} /$ duckling up to 56 days of age in previous findings. On the contrary, according to the present study, feed intake up to 56 days of age, in P X D was lower than that in P X J. This result contradicted with Modak (1996) and Ferdaus (1999). They reported that feed intake was higher in P X D (6078 g/duckling) and lower in P X J (5115 g/duckling).

Feed utilization was better in P X D crossbred than that in P X P and P X J. In case of P X P and P X J, the findings of this study agreed with Pingel and Jeroch (1969), Kozlowski (1976), Modak (1996) and Ferdaus (1999). During comparing feed conversion among the genotypes of P X P, P X J, they reported that feed conversion in P X P and P X J were 3.79 and 3.82 respectively. However, findings of Modak (1996) and Ferdaus (1999) contradict the results of this study in case of P X D (2.89) genotype. The feed conversion they obtained in P X D was 3.73.

Higher breast meat in P X P than that in P X D and P X J as found in this study coincide with the findings of Ferdaus (1999). Ferdaus (1999) observed that the breast meat in P X P, P X D and P X J was $15.59,14.83$ and $13.42 \%$ respectively. Superior thigh meat (\%) in P X D and P X P than that in P X J was recorded in this study which also agrees with Ferdaus (1999). According to the findings of Ferdaus (1999), thigh weight in P X P, P X D and P X J was $6.68,6.44$ and $6.19 \%$. 
Bang. J. Anim. Sci. 2008, 37(2)

\section{Conclusion}

It may be concluded that crossing of Pekin with the local ducks might produce a suitable genotype to improve meat production potential of duck reared under Bangladesh condition.

\section{Literature Cited}

Ahmed, S. (1986). Duck production in Bangladesh. In "Duck Production Science and World Practice". Farrell, D. J. and Stapleton, P. (Ed.). University of New England, Armidale, Australia, pp. 342-350.

Banerjee, G. C. (1992). Poultry ( ${ }^{\text {rd }}$ edition). Oxford and IBH Publishing Co. Pvt. Ltd. New Delhi, pp. 168-172.

Batty, J. (1979). Domesticated ducks and geese. Spur Publications, Saiga Publishing Co. Ltd. England, pp. 116 and 143.

DLS (1990). Livestock Population. Directorate of Livestock Services. Farmgate, Dhaka.

Edar, E., Yabuki, R., Takayama, K., Nakanishi, Y., Manda, M., Watanabe, S., Matsumota, S. and Nakagama, A. (1996). Comparative studies of behaviour, weeding and pest control of ducks (Mallard, Cherry Valley and their crossbred) free ranged in paddy field. Japanese Poultry Sci., 30: 365-370.

Ferdaus, A.J.M. (1999). Reproduction, growth and meat yield performance of different genotypes of ducks. MS Thesis, Department of Poultry Science, Bangladesh Agricultural University, Mymensingh.

Hussain, M. S., Abdin, M. S., Quddus, M. A., Hossain, A. M. M., Banu, T., Ara, S. and Ahmed, D. (1988). Women's contribution to the homestead agricultural production system in Bangladesh Academy for Rural Development, Kotbari, Comilla.

Jones, R. (1984). A standard method of dissection of poultry for carcass analysis. A technical Note No. 222. West of Scotland Agricultural College, Auchincruive Ayr, KA6 5HW, Scotland.

Khan, A. G. (1983). Improvement of Desi birds-part 2. Poultry Adviser. 16 : 67-78.

Kozlowski, M. (1976) Potato silage and rape seed oil meal for fattening broiler ducks. 1. Growth and carcass quality. Roczniki Nauk Rolniczych, B., 98(1) : 67-81. Cited by: Ferdaus, A. J. M. (1999). Reproduction, growth and meat yield performance of different genotypes of ducks. M.S. Thesis. Department of Poultry Science, Bangladesh Agricultural University, Mymensingh.

Manda, M., Uchida, H., Nakagama, A., Matsumoto, S., Shimoshikiryo, K. and Watanable, S. (1993). Effects of Aigamo ducks (crossbred of wild and domestic ducks) herding on weeding and pest control in the paddy fields. Japanese Poultry Sci. $30: 365-370$.

Modak, M. K. (1996). Meat yield performances of Pekin $\times$ Pekin, Pekin $\times$ Desi and Pekin $\times$ Khaki Campbell. MS Thesis, Department of Poultry Science, Bangladesh Agricultural University, Mymensingh.

Nageswara, A. R., Reddy, V., Ravindra., Reddy, V., Ramasubba and Eshwaraiah, (1998). Comparative performance of Khaki Campbell, Indian non-descriptive ducks and their reciprocal crosses during growing period. Indian J. Poult. Sci. 33(1) : 106-109. 
Pingel, H. and Jeroch, H. (1969). Investigations on fattening and carcass performance as well as meat quality of Muscovy drake X Pekin duck crossbred; Animal Breeding Abstract. 40(3) : 578.

Salauddin, M., Barua, A., Rashid, N. and Howlider, M. A. R. (1991). A study on the relationship of egg weight with fertility and hatchability of Desi ducks. Poultry Guide. 28(3) : 34-37.

Yeong, S. W. (1986). Utilization of local feed stuffs in diets of meat and laying ducks in Malaysian. In: Duck Production Science and World Practice. Fasell, D. J. and Stapleton, P. (Ed.) University of New England. Armidale, Australia, pp. 323-332. 